\title{
Implementation Of Webqual 4.0 For Measuring The Quality Of Baznas.Go.Id Website For User Satisfaction
}

\author{
Acmad Nurhadi \\ Sistem Informasi Kampus Kota \\ Pontianak Universitas Bina Sarana \\ Informatika, Indonesia \\ achmad.ahh@bsi.ac.id
}

Anna Mukhayaroh

Sistem Informasi Sekolah Tinggi

Manajemen Informatika dan

Komputer Nusa Mandiri, Indonesia

anna.auh@nusamandiri.ac.id

\author{
Norma Yunita \\ Sistem Informasi Kampus Kota \\ Pontianak Universitas Bina Sarana \\ Informatika, Indonesia \\ norma.nyt@bsi.ac.id \\ Ahmad Sahirudin \\ Sistem Informasi Sekolah Tinggi \\ Manajemen Informatika dan \\ Komputer Nusa Mandiri, Indonesia \\ a.sahirudin@gmail.com
}

\begin{abstract}
Through Presidential Instruction No. 3 Th 2003, the government in this case the Ministry of Communication and Information has set a National Policy and Strategy on the development of e-government in the use of communication and information technology to improve the efficiency, effectiveness, transparency and accountability of a Department. So that demanded a quality government website. Based on that, this study tries to measure the quality of government websites, namely www.baznas.go.id. which is viewed from the side of user satisfaction using the webqual 4.0 method, which consists of three dimensions, namely usability, information quality and interaction quality. The results of this study that the dimensions of information quality and usability have an influence on website users.
\end{abstract}

Keywords- Webqual, Website Quality, E-Government

\section{INTRODUCTION}

At present the development of technology, information and telecommunications can be felt and utilized by the wider community. Such rapid progress makes it easy for the people in Indonesia to get access information. Especially in terms of managing and channeling zakat, infaq and sodaqoh for Muslims in Indonesia. However, the Indonesian Waqf Agency assesses that there are several obstacles that cause the lack of distribution of zakat and waqf through the relevant institutions. One reason is the lack of public trust in the government so that they prefer the traditional way of tithe and endowments [4]. The absence of socialization regarding the functions of the amil zakat body and the absence of guidance carried out by amil zakat officers regarding the procedure of zakat to the muzakki [7].

In general, a government needs a system that can support the process of a service carried out in service violations. Where service can be interpreted as an effort to take care of what is needed by the community. All forms of service delivery have become the responsibility of the government in terms of meeting community needs.

The National Zakat Amil Agency (BAZNAS) is the only official body formed by the government based on Republic of Indonesia's Presidential Decree No. 8 of 2001 which has the task and function of collecting and distributing zakat, infaq, and alms (ZIS) at the national level. Given the vast territory in Indonesia, BAZNAS has made use of current technological advancements, as a means of information to facilitate and facilitate its programs which are located at baznas.go.id, where the website contains several information services regarding baznas. However, there are still some shortcomings in the service. Based on the research it can be concluded that service factors have a very large influence on the success of an e-government [9]. The 
development of e-government in Indonesia in quantity has begun to increase but has not been evenly distributed, but there are still many in quality that do not meet good standards. And the quality of the website is not yet standardized to get a good quality website. In order to create service interactions on the website properly. For this reason, quality measurement is needed on websitebaznas .go.id using the Webqual 4.0 method.

Previous research on webqual 4.0 method for measuring website service quality is research Warjiyono \& Hellyana. The purpose of this study was to find out the quality of Jagalempeni Village Government website using Webqual 4.0 method and it is hoped that Jagalempeni Village website will be better, better quality, have the competitiveness and pride of Jagalempeni Village in accordance with the ideals towards good governance [9]. Other research is research Khairunissa \& Wasiyanti for measuring depok government websites on user satisfaction with the webqual 4.0 method [3]. The next study is Rohman \& Kurniawan, namely measuring the quality of the national disaster management website using the webqual 4.0 method [1].

\section{THEORY}

\section{A. Webqual 4.0}

According to Slabey and Wahidin, webqual is a measurement based on quality function deployment (QFD). Webqual is a measurement to measure the quality of a website based on research instruments that can be categorized into three variables, namely: usability, information quality, and services interaction quality [8].

Webqual instruments use the approach of perception and importance of users. If webqual 1.0 emphasizes the quality of information analysis and has a lack of interaction services, webqual 2.0 is the opposite, which is more emphasis on analysis of interactions but feels less on the analysis of information quality. The two instruments were tried to be applied to a study of the quality of online auction sites. The results of the study indicate that site quality analysis is categorized into three different focus areas, namely: Site quality; The quality of information provided and the quality of interactions offered by the service. The results of this study are known as webqual 3.0. Further analysis of webqual 3.0 resulted in a webqual 4.0 model approach which eventually replaced the first dimension, namely site quality into the dimensions of Usability [2].

\section{B. Research Population and Samples}

Population is a generalization area consisting of objects or subjects that have certain qualities and characteristics set by researchers to be studied and and then drawn conclusions [6]. The population in this study are users who have used the facility or who have already carried out zakat, infaq, and alms distribution transactions on the baznas.go.id website. In this study, many baznas.go.id website users and their numbers are not known correctly.
Samples are part or number and characteristics possessed by the population [6]. If the population is large, and researchers are not likely to learn all that exists in the population, for example due to limited funds, energy and time, the researcher will take samples from that population, the conclusion will be applied to the population. For that samples taken from the population must be truly representative. The sample used in this study is a non probability sampling method, and sampling uses purposive sampling, namely the selection of samples with certain criteria.

\section{Likert Scale}

In this method, an assessment to determine the quality of baznas.go.id website services for users, the author uses a questionnaire designed with a Likert scale with instruments or dimensions using the webqual 4.0 method which consists of 4 dimensions, namely usability, information quality ( information quality), interaction quality (quality of interaction) and user satisfaction. For the scale of measuring the level of satisfaction, namely Strongly Agree (1), Agree (2), Neutral (3), Disagree (4), Strongly Disagree (5). The formula for knowing numerical scale evaluation intervals using the Likert scale is as follows:

Information:

$$
\mathrm{RS}=\frac{\mathrm{m}-\mathrm{n}}{\mathrm{b}}
$$

RS = Scale Range

$\mathrm{m}=$ highest number in measurement

$\mathrm{n}=$ lowest number in measurement

$\mathrm{b}=$ number of classes / categories formed

TABLE I. Likert Scale

\begin{tabular}{|l|c|c|}
\hline \multicolumn{1}{|c|}{ Information } & Code & Interval \\
\hline Strongly Disagree & STS & $1 \mathrm{~s} / \mathrm{d} 1,8$ \\
\hline Disagree & TS & $1,8 \mathrm{~s} / \mathrm{d} 2,6$ \\
\hline Neutral & $\mathrm{N}$ & $2,6 \mathrm{~s} / \mathrm{d} 3,4$ \\
\hline Agree & $\mathrm{S}$ & $3,4 \mathrm{~s} / \mathrm{d} 4,2$ \\
\hline Strongly Agree & $\mathrm{SS}$ & $>4,2$ \\
\hline
\end{tabular}

\section{Validity Test}

Test the validity of the questionnaire used to find out how carefully an item in measuring what you want to measure on the questionnaire [5]. Items can be said to be valid if there is a significant correlation with the total score. The analytical method used is the Pearson correlation method. The technique of testing validity with Pearson correlation is by correlating the item score with its total score. The total score is the sum of all items on a variable. Then the significance testing is done by criteria using $r$ table at a significance level of 0.05 with a 2 -sided test. If the 
value of $r$ count $\geq r$ table then the item can be declared valid, if $r$ count $<r$ table then the item can be declared invalid. To calculate the validity test manually are as follows:

$$
\text { R Hitung }=\frac{N \cdot \Sigma X Y-(\Sigma X) \cdot(\Sigma Y)}{\sqrt{\left\{N \Sigma X^{2}-(\Sigma X)^{2}\right\}-\left\{N \Sigma Y^{2}-(\Sigma Y)^{2}\right\}}}
$$

Information:

Rhitung $=$ Correlation coefficient between item score (X) with item score (Y)

$\mathrm{N}=$ Number of respondents

$\Sigma \mathrm{X}=$ Number of variable scores $(\mathrm{X})$

$\Sigma \mathrm{Y}=$ Number of variable scores $(\mathrm{Y})$

$\Sigma X 2=$ Number of squares of variable scores $(X)$

$\Sigma Y 2=$ Number of squares of variable scores $(Y)$

$\Sigma X Y=$ Number of product score multiplication with item score $(\mathrm{X})$ and score variable $(\mathrm{Y})$

\section{Reliability Test}

Reliability test is used to determine the consistency of measuring instruments on the questionnaire, meaning that the measuring instrument will get a measurement that remains consistent if the measurement is repeated again [5]. The method used for reliability testing is the Cronbach's Alpha method, with the following formula:

$$
r_{11}=\left[\frac{\mathrm{k}}{\mathrm{k}-1}\right]\left[1-\frac{\Sigma \sigma_{\mathrm{b}}^{2}}{\sigma_{\mathrm{t}}^{2}}\right]
$$

Information:

r11 = Instrument reliability

$\mathrm{k}=$ Number of questions

$\Sigma \sigma_{-} b^{\wedge} 2=$ Number of item variants

$\sigma_{-} \mathrm{t}^{\wedge} 2=$ Total variant

\section{RESULT}

\section{A. Validity Test}

At the stage of this validity test aims to be able to obtain results whether the questions on the questionnaire distributed to the respondent have been valid or not, as a relevant question, the intent and purpose of the respondent.

In this validity test the author uses the Pearson Correlation formula which will be implemented in the SPSS version 22 program. Test the validity of this $\mathrm{r}$ table using a significant level of 0.05 with a 2 -sided test with $\mathrm{N}=50$, then the results of the $\mathrm{r}$ table are
0.2787 , if $r$ count more large than $r$ table, then the question items can be declared valid. But, if $r$ count is smaller than $r$ table, then the question items are declared invalid.

TABLE II. Validity Test

\begin{tabular}{|c|c|c|c|}
\hline Question & R Count & R Table & Information \\
\hline \multicolumn{4}{|c|}{ Usability } \\
\hline P1 & 0,448 & 0,2787 & Valid \\
\hline P2 & 0,430 & 0,2787 & Valid \\
\hline P3 & 0,400 & 0,2787 & Valid \\
\hline P4 & 0,492 & 0,2787 & Valid \\
\hline P5 & 0,302 & 0,2787 & Valid \\
\hline P6 & 0,309 & 0,2787 & Valid \\
\hline P7 & 0,524 & 0,2787 & Valid \\
\hline \multicolumn{5}{|c|}{ Information Quality } \\
\hline P8 & 0,447 & 0,2787 & Valid \\
\hline P9 & 0,514 & 0,2787 & Valid \\
\hline P10 & 0,459 & 0,2787 & Valid \\
\hline P11 & 0,380 & 0,2787 & Valid \\
\hline P12 & 0,362 & 0,2787 & Valid \\
\hline P13 & 0,391 & 0,2787 & Valid \\
\hline P14 & 0,330 & 0,2787 & Valid \\
\hline \multicolumn{5}{|c|}{ Interaction Quality } \\
\hline P15 & 0,291 & 0,2787 & Valid \\
\hline P16 & 0,464 & 0,2787 & Valid \\
\hline P17 & 0,700 & 0,2787 & Valid \\
\hline P18 & 0,396 & 0,2787 & Valid \\
\hline \multicolumn{5}{|c|}{ Customer Satisfaction } \\
\hline P19 & 0,288 & 0,2787 & Valid \\
\hline P20 & 0,351 & 0,2787 & Valid \\
\hline P21 & 0,598 & 0,2787 & Valid \\
\hline P22 & 0,303 & 0,2787 & Valid \\
\hline P23 & 0,326 & 0,2787 & Valid \\
\hline
\end{tabular}

\section{B. Reliability Test}

The next stage is to do reliability testing which aims to determine the consistency level of the questionnaire stated reliable or not. The method used in this reliability testing is Alpa Cronbach's on SPPS 22 program. Decision making in this reliability test is if the Alpha value is greater than $r$ table, the questionnaire items can be declared reliable or consistent. Whereas, if the Alpha value is smaller than $r$ table, the questionnaire items are declared to be unreasonable or consistent.

The results of this reliability test show Alpha results with a value of 0.785543 , then the value is compared with the value of $r$ table and the significance of $5 \%$ is 0.278 , it can be concluded, that Alpha $=0.785543>\mathrm{r}$ table $=0.278$. then the items in the questionnaire to measure service quality on the baznas.go.id website can be declared reliable or consistent. 


\section{Webqual 4.0 Testing}

The following is the content of the questionnaire based on webqual dimensions and rules 4.0 which has been adjusted to the theme research.

TABLE III. Questionnaire

\begin{tabular}{|c|c|c|}
\hline No & $\begin{array}{l}\text { Variable } \\
\text { Name }\end{array}$ & Question \\
\hline \multicolumn{3}{|r|}{ Usability } \\
\hline 1 & $\mathrm{P} 1$ & $\begin{array}{l}\text { I feel easy to learn how to operate } \\
\text { the website }\end{array}$ \\
\hline 2 & $\mathrm{P} 2$ & $\begin{array}{l}\text { I feel clear and understand } \\
\text { interacting with the website }\end{array}$ \\
\hline 3 & P3 & $\begin{array}{l}\text { I feel easy to run menu from the } \\
\text { website }\end{array}$ \\
\hline 4 & $\mathrm{P} 4$ & I feel easy to use website \\
\hline 5 & P5 & $\begin{array}{l}\text { The website www.baznas.go.id/ } \\
\text { has attractive appearance }\end{array}$ \\
\hline 6 & P6 & $\begin{array}{l}\text { The website www.baznas.go.id/ } \\
\text { looks convincing and competent }\end{array}$ \\
\hline 7 & P7 & $\begin{array}{l}\text { The website www.baznas.go.id/ } \\
\text { gives positive thing for me }\end{array}$ \\
\hline \multicolumn{3}{|r|}{ Information quality } \\
\hline 8 & P8 & $\begin{array}{l}\text { The website www.baznas.go.id/ } \\
\text { gives accurate information }\end{array}$ \\
\hline 9 & P9 & $\begin{array}{l}\text { The website www.baznas.go.id/ } \\
\text { give reliable information }\end{array}$ \\
\hline 10 & P10 & $\begin{array}{l}\text { The website www.baznas.go.id/ } \\
\text { gives } \\
\text { information on time }\end{array}$ \\
\hline 11 & P11 & $\begin{array}{l}\text { The website www.baznas.go.id/ } \\
\text { gives accurate information }\end{array}$ \\
\hline 12 & $\mathrm{P} 12$ & $\begin{array}{l}\text { The website } \text { www.baznas.go.id/ } \\
\text { provides } \\
\text { information }\end{array}$ \\
\hline 13 & P13 & $\begin{array}{l}\text { The website www.baznas.go.id/ } \\
\text { gives precise information in detail }\end{array}$ \\
\hline 14 & P14 & $\begin{array}{l}\text { The website www.baznas.go.id/ } \\
\text { gives information in the } \\
\text { appropriate format }\end{array}$ \\
\hline \multicolumn{3}{|c|}{ Interaction Quality } \\
\hline 15 & $\mathrm{P} 15$ & $\begin{array}{l}\text { The website www.baznas.go.id/ } \\
\text { has good reputation }\end{array}$ \\
\hline 16 & P16 & $\begin{array}{l}\text { I feel safe when inputting data } \\
\text { personally on the website } \\
\text { www.baznas.go.id/ }\end{array}$ \\
\hline 17 & P17 & make room for personalization \\
\hline 18 & P18 & $\begin{array}{l}\text { provide services according to the } \\
\text { application presented }\end{array}$ \\
\hline \multicolumn{3}{|c|}{ Customer Satisfaction } \\
\hline 19 & P19 & $\begin{array}{l}\text { I like the look of thi } \\
\text { www.baznas.go.id/ website }\end{array}$ \\
\hline 20 & $\mathrm{P} 20$ & $\begin{array}{l}\text { I like the service on the } \\
\text { www.baznas.go.id/ website }\end{array}$ \\
\hline
\end{tabular}

\begin{tabular}{|l|l|l|}
\hline 21 & P21 & $\begin{array}{l}\text { I did not wait long to access the } \\
\text { www.baznas.go.id/ websit }\end{array}$ \\
\hline 22 & P22 & $\begin{array}{l}\text { the information provided by the } \\
\text { www.baznas.go.id/ website is very } \\
\text { useful for me }\end{array}$ \\
\hline 23 & P23 & $\begin{array}{l}\text { www.baznas.go.id/ website can be } \\
\text { accessed with a gadget }\end{array}$ \\
\hline
\end{tabular}

TABLE IV

The Results Of Questionnaire Processing

\begin{tabular}{|c|c|c|c|c|c|c|c|}
\hline Statement & SS & S & N & TS & STS & Amount & Avrg \\
\hline P1 & 14 & 29 & 6 & 1 & 0 & 206 & 4.12 \\
\hline P2 & 19 & 28 & 2 & 1 & 0 & 215 & 4.3 \\
\hline P3 & 14 & 27 & 8 & 1 & 0 & 204 & 4.08 \\
\hline P4 & 16 & 25 & 9 & 0 & 0 & 207 & 4.14 \\
\hline P5 & 21 & 17 & 12 & 0 & 0 & 209 & 4.18 \\
\hline P6 & 16 & 23 & 11 & 0 & 0 & 205 & 4.1 \\
\hline P7 & 9 & 31 & 9 & 1 & 0 & 198 & 3.96 \\
\hline P8 & 14 & 24 & 12 & 0 & 0 & 202 & 4.04 \\
\hline P9 & 20 & 23 & 7 & 0 & 0 & 213 & 4.26 \\
\hline P10 & 17 & 22 & 8 & 3 & 0 & 203 & 4.06 \\
\hline P11 & 11 & 26 & 12 & 1 & 0 & 197 & 3.94 \\
\hline P12 & 16 & 28 & 6 & 0 & 0 & 210 & 4.2 \\
\hline P13 & 15 & 31 & 3 & 1 & 0 & 210 & 4.2 \\
\hline P14 & 17 & 27 & 5 & 1 & 0 & 210 & 4.2 \\
\hline P15 & 16 & 20 & 14 & 0 & 0 & 202 & 4.04 \\
\hline P16 & 22 & 18 & 10 & 0 & 0 & 212 & 4.24 \\
\hline P17 & 14 & 29 & 5 & 2 & 0 & 205 & 4.1 \\
\hline P18 & 17 & 28 & 5 & 0 & 0 & 212 & 4.24 \\
\hline P19 & 18 & 26 & 6 & 0 & 0 & 212 & 4.24 \\
\hline P20 & 12 & 35 & 3 & 0 & 0 & 209 & 4.18 \\
\hline P21 & 13 & 23 & 13 & 1 & 0 & 198 & 3.96 \\
\hline P22 & 18 & 28 & 4 & 0 & 0 & 214 & 4.28 \\
\hline P23 & 16 & 32 & 2 & 0 & 0 & 214 & 4.28 \\
\hline
\end{tabular}

Obtained from the calculation of the table above, it shows that more dominantly gets interpretation in the Satisfied category, this shows the users or distributors of zakat, infaq, and sodaqoh are satisfied with the quality of the baznas.co.id website.

The data also shows the highest results in the information quality dimension with a total score of 1445 and an average score of 28.9. Then the lowest result is in the dimension of interaction quality with the total score of 831 and the average score of 16.62 .

\section{Conclusion}

Based on the results of research that has been done on the website baznas.go.id by using the method of webqual 4.0 and calculation of the Likert scale, the authors can describe some conclusions as follows: 
1.) For the information quality dimension has the most dominant influence with the highest average score of 28.9, while the one that has no influence is the interaction quality dimension with the lowest average score is 16.6 .

2.) Overall, the users of the baznas.go.id website are satisfied after using or conducting the distribution of zakat, infaq, and alms transactions with an average score of 28.9 .

\section{REFERENCES}

[1] Fathur Rohman, D. K . Pengukuran Kualitas Website Badan Nasional Penanggulangan Bencana Menggunakan Metode Webqual 4.0. Ilmu Pengetahuan Dan Teknologi Komputer, 3(1), 31-38. 2017.

[2] Hendradi, P., Sukendar, T., \& Saputro, M. I. Pengaruh Kualitas Website Pt Go-Jek Indonesia Terhadap Kepuasan Pengguna Menggunakan Metode Webqual Pendahuluan. Jurnal Satya Informatika, 2(2), 44-57. 2017.

[3] Khairunissa, \& Wasiyanti, S. Pengukuran Kualitas Website Pemerintah Depok Terhadap Kepuasan Pengguna Dengan Metode Webqual 4.0. Jurnal Swabumi, 6(1), 35-43. Https://Doi.Org/10.1016/J.Apnr.2014.11.001. 2018.

[4] Nadratuzzaman, M. (2016) Republika.co.id https://www.republika.co.id/berita/ekonomi/syariahekonomi/16/10/30/ofv2ed415-masyarakat-masih-tidakpercaya-pemerintah-salurkan-zakat.

[5] Prayitno, D. Panduan Praktis Olah Data Menggunakan SPSS. Yogyakarta: Andi. 2017.

[6] Sugiyono. Metode Peneltian Kuantitatif Kualitatif dan R \& B. Bandung: Alfabeta. 2011.

[7] Syafitra, M. Persepsi Normatif Masyarakat Terhadap Pembayaran Zakat Fitrah Melalui Lembaga Amil Zakat (Studi Di Kecamatan Mamajang Kota Makassar). Jurnal Tomalebbi, 3(4), 54-61. 2016.

[8] Syaifullah, \& Soemantri, Dicky Oksa. Pengukuran Kualitas Website Menggunakan Metode Webqual 4 . 0. Jurnal Rekayasa Dan Manajemen Sistem Informasi, 2(1), 19-25. 2016.

[9] Warjiyono, W., \& Hellyana, C. M. Pengukuran Kualitas Website Pemerintah Desa Jagalempeni Menggunakan Metode Webqual 4.0. Jurnal Teknologi Informasi Dan Ilmu Komputer, $5(2), \quad 139$. https://doi.org/10.25126/jtiik.201852666. 201. 